\title{
METHODOLOGICAL FRAMEWORK ON ENTREPRENEURIAL ORIENTATION AND INNOVATION IN THE PUBLIC SECTOR
}

\author{
Konstantinos M. Karyotakis, \\ Vassilis S. Moustakis
}

\author{
Management Systems Laboratory \\ (ManLab), School of Production \\ Engineering and Management \\ Technical University of Crete, \\ Chania, 73100, Greece
}

\begin{abstract}
:
This research aims to expand the conceptualization of the individual and organizational characteristics which are associated with organizational Entrepreneurial Orientation (EO) in public administration. It also attempts to provide organizations and their administrators, public officers, strategy and public policy makers, with a strong framework, supported by valuable information, on how to create an effective working environment which encourages the development of EO behavior. A theoretical framework and a theoretical methodological tool were designed in order to demonstrate such relations. By capturing the employee perceptions on attitudes, behavior and practices in their workplace, it is examined whether a public organization is innovative and entrepreneurial oriented. Knowing more about the observed variables, this research will provide information which would reveal the organizational and the individual characteristics which will support, promote and amplify the EO within the working environment of public organizations.
\end{abstract}

\section{Keywords:}

Public administration, entrepreneurship, innovation, individual characteristics, organizational characteristics, learning orientation, job satisfaction, employees perceptions, survey instrument.

\section{INTRODUCTION}

Looking superficially at the public sector, one easily contemplates the problems of the interaction between employees, government and citizens, such as operating costs, resource management and quality issues. Thus, the modern public administration has to behave in a more entrepreneurial and less bureaucratic way in order to harmonize with the dynamic, constantly evolving environment. Nevertheless, quantitative data, related to the reasons why (or not) civil servants adopt an Entrepreneurial Orientation behavior, are not sufficient yet $[1 ; 2 ; 3]$.

Innovative and entrepreneurial attitudes are nowadays highly valued for the re-engineering, reformation and adaptation of public (and not only) erstwhile bureaucratic organizations to the new conditions, not only for purposes of development and evolution but also for survival reasons in a gradually changed socio-economic, technological and political environ-

ment $[4 ; 5]$.
Correspondence:

Konstantinos M. Karyotakis

e-mail:

karyotakisk@gmail.com 


\section{THE THEORETICAL FRAME}

The concepts of entrepreneurial and innovative behavior

An EO and innovative behavior can greatly contribute to solving several issues of great importance in a public organization, while at the same time value is given to employees, processes, final results, generally speaking the organization and the society as a whole.

In this survey, the concept of entrepreneurial and innovative behavior has been approached from the angle of added value to the services provided, and not in the sense of financial gain. Undoubtedly, such a behavior inspires a whole new culture of change, which promotes creative and innovative thinking. Hence, a substantially positive contribution to community is achieved, through the implementation of district ideas which develop a fruitful and multivariable environment for citizens, as well as higher quality services.

This article provides a comprehensive review of the conceptual model of reference [5], including the further development and testing of the methodological framework analysis shown in Fig. 1. Henceforth, exploring the context of entrepreneurial and innovative behavior that governs a public organization, precisely it reflects perceptions that the employees themselves have on attitudes, behavior and practices promptly taking place on their job environment.

It is also well known that the $\mathrm{EO}$ of an organization enables managers to improve the quality and the effectiveness of their services. However, a more detailed analysis of the factors which are important to the EO is necessary with regards to unique means executives practise to act in a more entrepreneurial way. This study attempts to outline the framework that evaluates all questions raised on this matter.

\section{The main research question}

The authors answer the paper's research question by conducting a large-scale literature review in different research fields, all in one study. In this way, the authors aim also to enlighten dark aspects of related literature, such as innovation and entrepreneurship in the public administration. This research, therefore, is based on different data from studies on corporate entrepreneurship in private sector, with relatively little application in the public sector.

For example, supporters of the theory explain that, the employees' perceptions are shown to be of extreme importance, while civil servants are the backbone of public administration. However, their opinions and perceptions in most cases are ignored. Nevertheless, [6] argues that with respect to the action of middle managers, their perception of various factors is more important than the existence of the factors themselves. On the other hand, [7] agree that, in order for any entrepreneurial intentions to be completely understood, both individual and organizational characteristics should be considered equally.

The lack of explicit analogue regarding the interaction in behavior of executives in public administration and plain employees in their internal work environment, based on their perceptions as such (on employee level), leads to the following research question: "Which organizational characteristics of the public sector and which individual characteristics of its managers are the cornerstone of actual Entrepreneurial Orientation behavior in public administration?"

\section{ENGAGING HODGEPODGE: THE INNOVATIVE AND ENTREPRENEURIAL FACTORS}

The individual characteristics, such as pro-activeness and creative efficacy, as well as specific demographic characteristics of public officials, in conjunction with the organizational characteristics (internal work environment), such as management support systems, work discretion, rewards/ recognition and organizational boundaries of public sector are being closely examined to establish whether they provide self-reported organizational EO. Technically, this process filters the mediators of organizational learning and job satisfaction (auxiliary variables) with regards to the moderating effects of resources' availability (intervening factor/ amending variable), in relation to organizational learning, job satisfaction and EO.

In this direction, it is expected for some factors to be full mediators (e.g. organizational characteristics) while others partial mediators (e.g. individual characteristics). In Fig. 1 is depicted the conceptual model of the present analysis in direct relation with the research-driven factors. Despite the results, the theoretical model, presented in this study, must be tested further using empirical data in order to be determined as full or partial, in its application.

Likewise, it should be noted that in this study, entrepreneurial behavior of middle managers is considered to be the key factor of corporate entrepreneurship [8; 9; 10], which directly affects the organizational EO [11]. 


\section{Research methodology}

Additionally, in order to prove empirically the validity of the theoretical model used below (Fig. 1) in this crosssectional study, a structured questionnaire was carefully designed using combined tools and multiple elements, according to the conceptual model, which have been developed, in their majority, by other researchers in the field; see for instance $[8 ; 12 ; 13 ; 14 ; 15 ; 16]$.

In spite of the general structural model, there have been several revisions and adjustments, aiming to a generated tool, applicable to public sector executives. Furthermore, after the main research process, expert groups meeting and pilot testing, four newly created items (see Table VI) lead to more accurate results for the initial methodological framework. The target is to examine the interconnection between the implication of the research model factors and their relations.

Consequently, taking into consideration the above mentioned factors, the methodological tool consists of a total of 70 questions. Among them, seven items were negatively worded to evade response tendencies by the subject [17]. The tool also includes demographic features and a factor concerning the Instructional Manipulation Check (IMC).

Tables I-V concisely present the cornerstone of the literature review used as an inspiration for the theoretical model (Fig. 1) and the corresponding theoretical framework, both of which support the findings of this research.

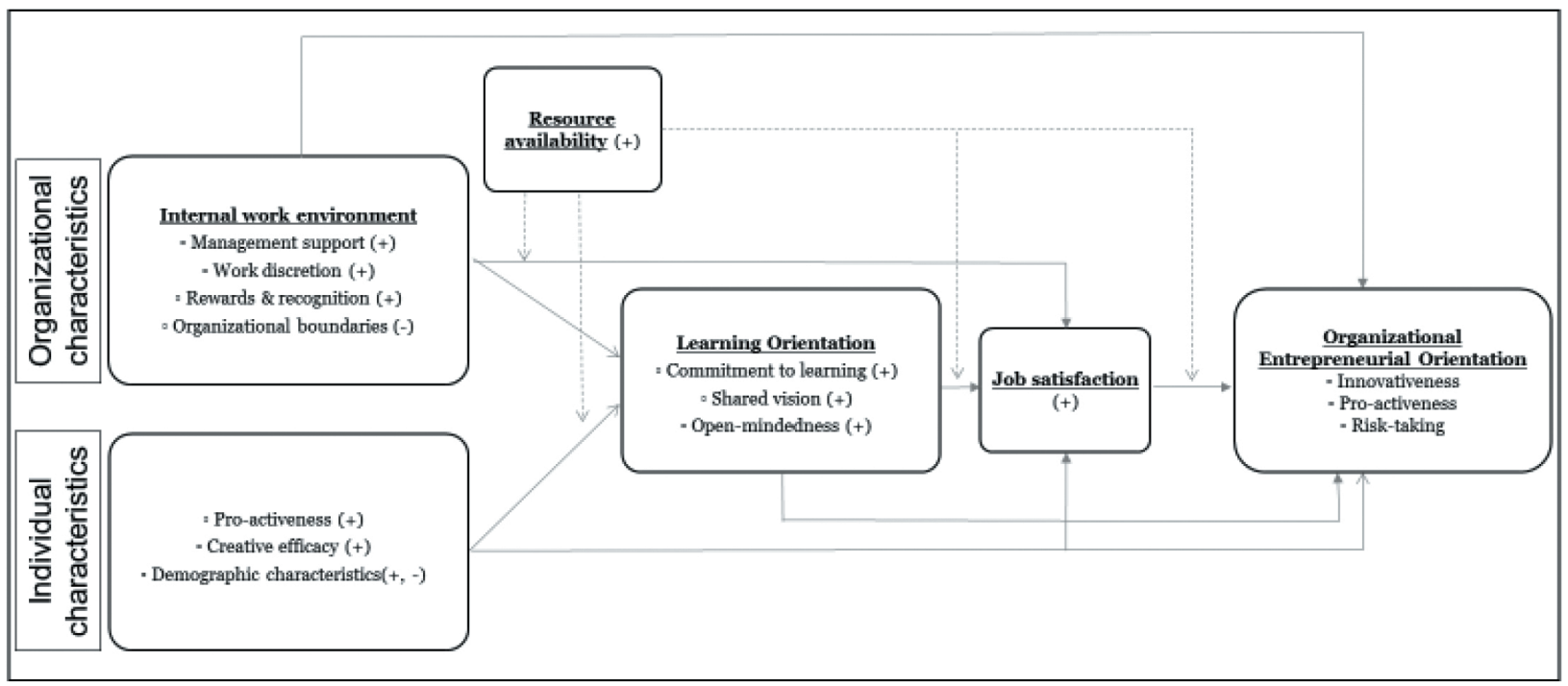

Note: Parentheses contain expected direction of effect.

$\rightarrow$ : Direct effect

: Moderating effect

Fig. 1. The heuristic model illustrates the effects of organizational and individual factors on job satisfaction through Learning Orientation (mediator) and the effects of LO on EO through job satisfaction (mediator). Moderating effects suggest that resource availability strengthens the LO (through organizational and/or individual characteristics) and the job satisfaction to EO relationship. 


\begin{tabular}{|c|c|c|}
\hline \multirow[b]{2}{*}{$\begin{array}{l}\text { Internal work } \\
\text { environment }\end{array}$} & \multicolumn{2}{|c|}{ Definition of variables } \\
\hline & $\begin{array}{c}\text { Number of } \\
\text { questions } \\
\text { (items) }\end{array}$ & $\begin{array}{l}\text { Operational } \\
\text { Definition }\end{array}$ \\
\hline Management support & 2 & {$[1 ; 8 ; 13]$} \\
\hline Work discretion & 4 & {$[8 ; 13]$} \\
\hline Rewards/ recognition & 3 & {$[1 ; 8 ; 13]$} \\
\hline $\begin{array}{l}\text { Organizational } \\
\text { boundaries }\end{array}$ & 4 & {$[8 ; 13]$} \\
\hline Total & 13 & \\
\hline
\end{tabular}

Table 1. Organizational characteristics

\begin{tabular}{lcc}
\hline & \multicolumn{2}{c}{ Definition of variables } \\
\cline { 2 - 3 } & $\begin{array}{c}\text { Number of } \\
\text { questions } \\
\text { (items) }\end{array}$ & $\begin{array}{c}\text { Operational } \\
\text { Definition }\end{array}$ \\
\hline Proactivity & 9 & {$[12 ; 14 ; 18]$} \\
\hline Creative efficacy & 3 & {$[16 ; 18]$} \\
\hline Total & 12 & \\
\hline
\end{tabular}

Table 2. Individual characteristics

\begin{tabular}{lcc}
\hline \multicolumn{1}{c}{$\begin{array}{c}\text { I. Learning } \\
\text { Orientation }\end{array}$} & \multicolumn{2}{c}{ Definition of variables } \\
\cline { 2 - 3 } & $\begin{array}{c}\text { Number of } \\
\text { questions } \\
\text { (items) }\end{array}$ & $\begin{array}{c}\text { Operational } \\
\text { Definition }\end{array}$ \\
\hline $\begin{array}{l}\text { Commitment to } \\
\text { learning }\end{array}$ & 4 & $\begin{array}{c}15 ; 19 ; 20 ; 21 ; 22 ; \\
23 ; 24 ; 25 ; 26]\end{array}$ \\
\hline Shared vision & 3 & {$[15 ; 19 ; 20 ; 25]$} \\
\hline Open-mindedness & 4 & {$[23]$} \\
\hline II. Job satisfaction & 6 & {$[23 ; 27 ; 28 ; 29 ; 30 ;$} \\
\hline Total & 17 & \\
\hline
\end{tabular}

Table 3. Moderator factor

\begin{tabular}{lcc}
\hline & \multicolumn{2}{c}{ Definition of variables } \\
\cline { 2 - 3 } & $\begin{array}{c}\text { Number } \\
\text { of } \\
\text { questions } \\
\text { (items) }\end{array}$ & $\begin{array}{c}\text { Operational } \\
\text { Definition }\end{array}$ \\
\hline Resource availability & $5^{\mathrm{i}}$ & {$[1 ; 8 ; 13 ; 23 ; 34]$} \\
\hline Total & 5 & \\
\hline
\end{tabular}

Table 4. Moderator factor

$i$ The current survey resulted two outcomes, as shown in Table VI.

\begin{tabular}{lcc}
\hline \multicolumn{1}{c}{$\begin{array}{c}\text { Entrepreneurial } \\
\text { Orientation } \\
\text { (EO) }\end{array}$} & \multicolumn{2}{c}{ Definition of variables } \\
\cline { 2 - 3 } & $\begin{array}{c}\text { Number } \\
\text { of } \\
\text { questions } \\
\text { (items) }\end{array}$ & $\begin{array}{c}\text { Operational } \\
\text { Definition }\end{array}$ \\
\hline Innovativeness & 2 & {$[1]$} \\
\hline Pro-activeness & $4^{\text {ii }}$ & {$[1]$} \\
\hline Risk-taking & 3 & {$[1 ; 23 ; 26 ; 35 ; 36 ;$} \\
$3738]$
\end{tabular}

Table 5. Outcome variable

\begin{tabular}{|c|c|c|}
\hline \multirow[b]{2}{*}{ New items } & \multicolumn{2}{|c|}{ Definition of variables } \\
\hline & $\begin{array}{c}\text { Number of } \\
\text { questions } \\
\text { (items) }\end{array}$ & $\begin{array}{l}\text { Operational } \\
\text { Definition }\end{array}$ \\
\hline $\begin{array}{l}\text { Pro-activeness } \\
\text { (organizational) }\end{array}$ & 2 & $\begin{array}{l}\text { 1. My organiza- } \\
\text { tion respects the } \\
\text { individuality of its } \\
\text { employees. } \\
\text { 2. My organization } \\
\text { is trying to create } \\
\text { a promising work } \\
\text { environment which } \\
\text { improves the } \\
\text { quality and ef- } \\
\text { ficiency of everyday } \\
\text { work. }\end{array}$ \\
\hline Resource availability & 2 & $\begin{array}{c}\text { 1. In my } \\
\text { organization, } \\
\text { operations are } \\
\text { performed with } \\
\text { respect to } \\
\text { a) quality and } \\
\text { b) predetermined } \\
\text { time schedules. } \\
\text { 2. In my } \\
\text { organization, every } \\
\text { employee achieves } \\
\text { maximum ef- } \\
\text { ficiency, using } \\
\text { effectively all } \\
\text { resources available. }\end{array}$ \\
\hline Total & 4 & \\
\hline
\end{tabular}

Table 6. New elements

Restrictions and future research

It should be noted that the suggested empirical part of this research will be based on collective data of single informants (individuals), whose participation is usually voluntary. Furthermore, the data of this research would probably involve objective measures, which, even though they can provide valuable information, can further require careful interpretation in an attempt to avoid common

ii The current survey resulted two outcomes, as shown in Table VI. 
mistakes, such as systematic biases (e.g. socially acceptable) related to the respondent [39]. A common method variance could thus be observed [40].

Moreover, the nature of the data which will be collected restricts the variety of the conclusions and analysis methods used. Hence, using cross-sectional data definitely requires special attention before conclude to causal inferences.

Although the interconnection of the spoken relationships will be identified through the survey, the results may be influenced by external variables which are not included in the present analysis or is susceptible to reverse causality [41].

In addition, despite the fact that hypotheses are based on theoretical factors and theoretical considerations, the relationships which will be identified could be the basis for mechanisms other than those taken into account for this survey. After all, longitudinal data, especially reflecting progress over time, could be used to overcome such uncertainty.

Last but not least, one can easily assume that all impartial relations and flimsy assumptions could be considered limitations of this analysis. Nevertheless, these could be used as part of future research data. For this reason, it would be interesting to give a thorough consideration to the interconnection of the less significant relations.

Undeniably, future research is needed to further examine more objective indicators and multiple sources. However, the generalization of this study, by applying the questionnaire to a large variety of public organizations instead of solitary examples, implements a far more accurate result and represents widely the diversity of demographic groups.

\section{SIGNIFICANCE OF THE STUDY}

This study was conducted due to the limited knowledge of EO in public administration applications, enforced by the influence of individual and organizational characteristics of public officials.

Noteworthy, here is the fact that it is essential to appreciate public servants by virtue of innovative and entrepreneurial solutions, improving the quality of provided services, identifying and creatively solving the issues that arise in their work. Along with a more organizational EO, the public sector can secure the effectiveness and efficiency of public administration system [42].

Moreover, the public administration policy makers, renouncing its bureaucratic facet, should focus on a more extraneous orientation, contouring the appropriate circumstances in order to meet the social needs through high quality services, of increased effectiveness and efficiency, in a highly globalized and competitive environment [43].

Indeed, public servants should be encouraged to adopt innovative and entrepreneurial attitudes and behavior, concerning daily problems and solutions. Executive training programs should also follow this approach.

Unquestionably, Entrepreneurial Orientation and innovative behavior can thrive in the public sector. $\mathrm{Ab}$ solutely, public executives, administrators, strategy and public policy makers should be focused on this direction.

\section{ACKNOWLEDGMENT}

K. M. Karyotakis would like to express his sincere gratitude for the tremendous support through the grant of "The Alexander S. Onassis Foundation" Scholarship.

\section{REFERENCES}

[1] T. Meynhardt, and F.E. Diefenbach, "What drives Entrepreneurial Orientation in the public sector? Evidence from Germany's Federal Labor Agen $\neg c y$ ", Journal of Public Administration Research and Theory, 22(4), pp. 761-792, April 2012.

[2] C. Kearney, R. Hisrich, and F. Roche, "A conceptual model of public sector corporate entrepreneurship", International Entrepreneurship and Management Journal, 4(3), pp. 295-313, September 2008.

[3] P. Teske, and M. Schneider, "The bureaucratic entrepreneur: the case of city managers", Public Administration Review, 54(4), pp. 331-340, July - August 1994.

[4] K.M. Karyotakis, and V.S. Moustakis, "Innovating in public administration" (in Greek), in 12th Student Conference of Science and Technology, Athens: Athens University of Economics and Business \& Hellenic Management Association, pp. 114-124, May 2015.

[5] K.M. Karyotakis, and V.S. Moustakis, "Organizational factors, organizational culture, job satisfaction and entrepreneurial orientation in public administration", The European Journal of Applied Economics, 13(1), pp. 47-59, April 2016.

[6] D.E. Marginson, "Management control systems and their effects on strategy formation at middle-management levels: evidence from a UK organization", Strategic management journal, 23(11), pp. 10191031, September 2002. 
[7] L. Lee, P.K. Wong, M. Der Foo, and A. Leung, "Entrepreneurial intentions: the influence of organizational and individual factors", Journal of business venturing. 26(1), pp. 124-136, January 2011.

[8] J.S. Hornsby, D.F. Kuratko, and S.A. Zahra, "Middle managers' perception of the internal en $\neg$ vironment for corporate entrepreneurship: as $\neg$ sessing a measurement scale", Journal of Business Venturing, 17(3), pp. 253-273, May 2002.

[9] J.S. Hornsby, D.F. Kuratko, D.A. Shepherd, and J.P. Bott, "Managers' corporate entrepreneurial actions: examining perception and position", Journal of Business Venturing. 24(3), pp. 236-247, May 2009.

[10] D.F Kuratko, J.S. Hornsby, and J.W. Bishop, "Managers' corporate entrepreneurial actions and job satisfaction", The International Entrepreneurship and Management Journal. 1(3), pp. 275-291, September 2005.

[11] J.A. Pearce, T.R. Kramer, and D.K. Robbins, "Effects of managers' entrepreneurial behavior on subordinates", Journal of Business Venturing, 12(2), pp. 147-160, March 1997.

[12] T.S. Bateman, and J.M. Crant, "The proactive component of organizational behavior: a measure and correlates", Journal of organizational behavior, 14(2), pp. 103-118, March 1993.

[13] D.F. Kuratko, J.S. Hornsby, and J.G. Covin, "Diag $\neg$ nosing a firm’s internal environment for corporate entrepreneurship", Business Horizons, 57(1), pp. 37-47, January - February 2014.

[14] S.E. Seibert, J.M. Crant, and M.L. Kraimer, "Proactive personality and career success", Journal of applied psychology, 84(3), pp. 416-427, June 1999.

[15] J.M. Sinkula, W.E. Baker, and T. Noordewier, “A framework for market-based organizational learning: linking values, knowledge, and behaviour", Journal of the academy of Marketing Science, 25(4), pp. 305-318, September 1997.

[16] P. Tierney, "The influence of cognitive climate on job satisfaction and creative efficacy", Journal of Social Behavior and Personality, 12(4), pp. 831-847, December 1997.

[17] D.R. Cooper, and C.W. Emory, Business Research Methods, 5th ed., Homewood, IL: Irwin, 1995.

[18] P.K. Baumann, “The Relationship between individual and organizational characteristics and nurse innovation behaviour", Doctoral dissertation, faculty of the University Graduate School in partial fulfillment of the requirements for the degree Doctor of Philosophy in the School of Nursing, Indiana University, April 2011.
[19] W.E. Baker, and J.M. Sinkula, “The synergistic effect of market orientation and learning orientation on organizational performance", Journal of the academy of marketing science, 27(4), pp. 411-427, October 1999.

[20] R.J. Calantone, S.T. Cavusgil, and Y. Zhao, "Learning orientation, firm innovation capability, and firm performance", Industrial marketing management, 31(6), pp. 515-524, September 2002.

[21] G.S. Day, “Continuous learning about markets", California Management Review, 36(4), pp. 9-31, Summer 1994.

[22] G. Galer, and K. Van Der Heijden, “The learning organization: how planners create organizational learning”, Marketing Intelligence \& Planning, 10(6), pp. 5-12, December 1992.

[23] M. García-Goñi, A. Maroto, and L. Rubalcaba, "Innovation and motivation in public health professionals", Health Policy, 84(2), pp. 344-358, December 2007.

[24] H. Keskin, "Market orientation, learning orientation, and innovation capabilities in SMEs: an extended model", European Journal of innovation management, 9(4), pp. 396-417, October 2006.

[25] M.L. Santos-Vijande, M.J. Sanzo-Perez, L.I. Alvarez-Gonzalez, and R. Vazquez-Casielles, "Organizational learning and market orientation: interface and effects on performance", Industrial marketing management, 34(3), pp. 187-202, April 2005.

[26] C.L. Wang, "Entrepreneurial Orientation, learning orientation, and firm performance", Entrepreneurship theory and practice, 32(4), pp. 635-657, July 2008.

[27] Hellenic Ministry of Finance, "Priorities diagnostic research and job satisfaction of employees of the General Secretariat of Public Revenue" (in Greek), 2014.

[28] D.B. Lund, "Organizational culture and job satisfaction", Journal of business \& industrial marketing, 18(3), pp. 219-236, June 2003.

[29] K. Parry, and S. Proctor-Thomson, "Leadership, culture and performance: the case of the New Zealand public sector", Journal of Change Management, 3(4), 376-399, February 2003.

[30] J.L. Price, and C.W. Mueller, "Absenteeism and turnover of hospital employees”, Greenwich, Conn: JAI press, 1986.

[31] T.A. Wright, and D.G. Bonett, "Growth coping, work satisfaction and turnover: a longitudinal study", Journal of Business and Psychology, 6(1), pp. 133-145, September 1991.

[32] T.A. Wright, and R. Cropanzano (1998), "Emotional exhaustion as a predictor of job performance and voluntary turnover", Journal of applied psychology, 83(3), pp. 486-493, June 1998. 
[33] B.E. Wright, and B.S. Davis, "Job satisfaction in the public sector. the role of the work environment", The American Review of Public Administration, 33(1), pp. 70-90, March 2003.

[34] I. Ma Prieto, and M. Pilar Perez-Santana, "Man $\neg$ aging innovative work behavior: the role of human resource practices", Personnel Review, 43(2), pp. 184-208, March 2014.

[35] J.G. Covin, and D.P. Slevin, D.P., "The development and testing of an organizational-level entrepreneurship scale", in Frontiers of Entrepreneurship Research, R. Ronstadt, J.A. Hornaday, and K.H. Vesper, Eds. Wellesley, MA: Babson College, 1986, pp. 628-639.

[36] J.G. Covin, and D.P. Slevin, "Strategic management of small firms in hostile and benign environments", Strategic management journal, 10(1), pp. 75-87, January 1989.

[37] D. Miller, "The correlates of entrepreneurship in three types of firms", Management Science, 29(7), pp. 770-791, July 1983.

[38] J.L. Naman, and D.P. Slevin, "Entrepreneurship and the concept of fit: a model and empirical tests", Strategic management journal, 14(2), pp. 137-153, February 1993.
[39] D.F. Polit, and C.T. Beck, Nursing research: principles and methods, 7th ed., Philadelphia: Lippincott Williams \& Wilkins, 2004.

[40] P.M. Podsakoff, S.B. MacKenzie, J.Y. Lee, and N.P. Podsakoff, "Common method biases in behavioral research: a critical review of the literature and recommended remedies", Journal of applied psychology, 88(5), pp. 879-903, November 2003.

[41] K. Backhaus, B. Erichson, W. Plinke, and R. Weiber, Multivariate analysis methods: an application oriented introduction (in German), Berlin: SpringerGabler, 2015.

[42] K.M. Karyotakis, M. Bakatsaki, and V.S. Moustakis, "The entrepreneurial facets of public ad $\neg$ ministration", in Synthesis In $\neg$ ternational Scientific Conference of IT and Business - Related Research, Belgrade: Singidunum University, pp. 327331, April 2015.

[43] K.M. Karyotakis, and V.S. Moustakis, "Reinvention of the public sector: Total Quality Management and change management", Singidunum Journal of Applied Sciences, 11(2), pp. 30-44, November 2014. 